\title{
Przeszłe przyszłości. Afektywne fakty i historie alternatywne
}

Justyna Tabaszewska 


\section{Przeszłe przyszłości. Afektywne fakty i historie alternatywne}

Justyna Tabaszewska

TEKSTY DRUGIE 2017, NR 5, S. 48-69

DOI: $10.18318 /$ td.2017.5.4
Badania zostały

sfinansowane ze środków

Narodowego Centrum

Nauki przyznanych

w ramach finansowania

stażu po uzyskaniu stopnia

naukowego doktora na

podstawie decyzji numer

DEC-2014/12/S/HS2/00079.

\section{Uwagi wstępne}

Powstająca po roku 1989 polska literatura, którą najczęściej określamy mianem najnowszej, nie zawsze cieszyła się - i do tej pory nie zawsze się cieszy - dobrą sławą wśród krytyków i badaczy. Powszechne w latach 90. narzekania, dotyczące braku 'nowej' powieści, powieści na miarę czasów, na miarę dokonującej się transformacji politycznej i gospodarczej, zaczęły jednak w latach 2000 słabnąć, a pozycja najnowszej literatury - wzmacniać się. To swoiste oswojenie nowej literatury, które dokonuje się w ostatnich latach, częściowo spowodowane jest na pewno narastającym dystansem czasowym, który prawie zawsze pozwala lepiej dostrzec, co jest cennego w najnowszych tekstach, co stanowi o ich wartości i decyduje o przynależności do określonego prądu, epoki czy okresu. Jednak wydaje się, że nie tylko upływ czasu sprzyja lepszemu odczytaniu powstających po roku 1989 książek, że do ich oswojenia i zaanektowania przyczyniło się jeszcze coś. Moim zdaniem, tym 'czymś jeszcze' jest zasadnicza zmiana trybów i kategorii interpretacyjnych.

\section{Justyna}

Tabaszewska

- doktor nauk

humanistycznych,

autorka książek/edna

przyroda czy przyrody

alternatywne? O poj-

mowaniu i obrazach

przyrody w polskiej

poezji i Poetyki pamię-

ci.Współczesna poezja

wobec tradycji i pa-

mięci oraz artykułów

publikowanych m.in.

W "Tekstach Drugich"

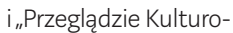
znawczym." Aktualnie pracuje w Instytucie

Badań Literackich nad projektem „Afektywne poetyki pamięci.

Polska literatura i kultura wobec przełomu roku 1989." Kontakt: justyna.tabaszewska@uj.edu.pl 
Ostatnie lata w badaniach nad literaturą i kulturą upływają pod znakiem między innymi - rosnącej ekspansji studiów nad pamięcią i nad afektami. Oczywiście, nie tylko te kierunki badawcze zyskały w ciągu kilku, kilkunastu minionych lat na znaczeniu, lecz one wydają się szczególnie istotne dla analizy polskiej kultury, uwikłanej mocniej chyba niż większość innych europejskich kultur w problemy związane z przeszłością, pamięcią o niej i częściowo powiązane - afektywne dylematy skorelowane ze zmieniającą się, coraz trudniej uchwytną teraźniejszością i przyszłością.

Pamięciowa i afektywna perspektywa badawcza jest moim zdaniem kuszącym i płodnym intelektualnie sposobem interpretowania dokonujących się w ostatnich latach zmian kulturowych. O tym, jak skuteczne może to być narzędzie analizy współczesnej kultury przekonują najnowsze prace badawcze, operujące wspomnianymi kategoriami w odniesieniu do różnych pól badawczych, zarówno literatury (za szczególnie istotne można uznać tu teksty Ryszarda Nycza', Marka Zaleskiego' ${ }^{2}$, Grzegorza Niziołka ${ }^{3}$, Katarzyny Bojarskiej $^{4}$, Moniki Glosowitz ${ }^{5}$ i Marii Kobielskiej ${ }^{6}$, odnoszące się do odmiennych typów i gatunków literackich), jak i sztuk performatywnych (Małgorzata Sugiera ${ }^{7}$ ), sztuki (Luzia Nader ${ }^{8}$ ), czy wreszcie dotykające skomplikowanego pola funkcjonowania afektów w odniesieniu do pamięci kulturowej (Roma

1 Por. R. Nycz Poetyka doświadczenia. Teoria-nowoczesność - literatura, Wydawnictwo IBL PAN, Warszawa 2012.

2 Por. M. Zaleski Estetyka zmąconych afektów, czyli estetyka zwykłości - o Dorocie Masłowskiej dwukrotnie, w: Historie afektywne i polityki pamięci, red. E. Wichrowska i in., Wydawnictwo IBL PAN, Warszawa 2015 oraz tegoż Niczym mydło w grze w scrabble, „Teksty Drugie” 2013 nr 6.

3 Por. G. Niziołek Polski teatr Zagłady, Instytut Teatralny im. Zbigniewa Raszewskiego i Wydawnictwo Krytyki Politycznej, Warszawa 2013.

4 Por. zwłaszcza K. Bojarska Wydarzenia po Wydarzeniu. Białoszewski-Richter-Spiegelman, Wydawnictwo IBL PAN, Warszawa 2012, oraz Poczuć myślenie: afektywne procedury historii i krytyki (dziś), "Teksty Drugie" $2013 \mathrm{nr} 6$.

5 Por. zwłaszcza M. Glosowitz, Niemożliwe światy /ustyny Bargielskiej: lektura afektywna, „Śląskie Studia Polonistyczne" 2014 t. 1/2 (5).

6 M. Kobielska Polska kultura pamięci wXXI wieku: dominanty. Zbrodnia katyńska, powstanie warszawskie i stan wojenny, Wydawnictwo IBL PAN, Warszawa 2016.

7 Por. projekt "Performanse pamięci: strategie testymonialne, rekonstrukcyjne i kontrfaktyczne w literaturze i sztukach performatywnych XX i XXI wieku" oraz M. Sugiera Wojny światów. Alternatywne scenariusze poczq̨tku XXI wieku, w: Zrozumieć obcość. Recepcja literatury niemieckojęzycznej w Polsce po 1989 roku, red. M. Wolting, S. Wolting, Universitas, Kraków 2016.

8 L. Nader Afektywna historia sztuki, „Teksty Drugie” $2014 \mathrm{nr} 1$. 
Sendyka9 ${ }^{9}$. Jednak, jak każda perspektywa badawcza, i ta posiada swoje problemy i ograniczenia. Jednym z największych, stale występujących i powtarzających się, są spory - w przypadku studiów afektywnych - dotyczące sposobu definiowania afektu, gdyż zarówno polscy, jak i zagraniczni badacze czerpią przynajmniej z kilku tradycji definiowania tej kategorii. W tym artykule chciałabym przyjąć jako perspektywę badawczą teorie dotyczące funkcjonowania afektu, stworzone przez Briana Massumiego. Nie jest to zaskakująca decyzja, gdyż Massumi od pierwszej dekady XXI wieku jest jednym z najbardziej rozpoznawalnych i szanowanych badaczy pracujących nad problematyką afektu, silnie inspirującym również polskich naukowców. Jednak, jak postaram się - przynajmniej szkicowo - pokazać, przyjmowane przez badacza rozumienie afektu po pierwsze ewoluuje, po drugie zaś - staje się coraz bardziej interesujące, zwłaszcza z perspektywy badań nad polską kulturą.

\section{Od afektu do ontosiły (ontopower)}

Definicja afektu, jaką przyjmuje Massumi, nie zmienia się znacząco od czasu tez wyrażonych w Parables for the Virtual, książce, która stanowiła podwaliny dla przynajmniej jednego kierunku rozwoju studiów nad afektami. We wspomnianej publikacji, badacz, określając afekt, odwołuje się głównie do teorii Barucha Spinozy, zgodnie z którą filozof charakteryzował ciało w kategoriach ruchu i spoczynku, z czym wiązało się jego twierdzenie, że ciało ma zdolność do wchodzenia w relacje, a co za tym idzie - moc i potencjał do odziaływania i bycia przedmiotem oddziaływania ${ }^{10}$, do tworzenia afektu i odbierania go. Ta najprostsza definicja afektu pozostaje w zasadzie bez zmian, choć kolejne książki i wypowiedzi Massumiego komplikują i zarazem uszczegóławiają wspominaną charakterystykę. W swojej kolejnej książce badacz mocniej akcentuje transaktywny charakter afektu, zwracając uwagę, że zdolność oddziaływania i odczuwania czyjegoś działania wymaga umiejętności zmiany - bycia zarówno pasywnym, jak i aktywnym, przechodzenia od jednego odczucia, do innego"1.

B. Massumi Parables for the Virtual. Movement, Affect, Sensation, Duke University Press, Durham-London 2002, S. 15. 
Od samego początku, w teoriach Massumiego, afekt jest czymś innym niż emocje, choć emocje mogą być również afektami. Czyniąc to rozróżnienie, Massumi podkreśla, że emocje są kontekstualne, afekty - sytuacyjne, emocje umiemy zazwyczaj nazwać i zinterpretować, afekty zaś posiadają o wiele szersze spektrum działania, często przekraczając emocje, będąc ich specyficzną kontynuacją lub rozszerzeniem ${ }^{12}$. Jak zauważa w Politics of Affect:

Emocja jest tylko częściową ekspresją afektu. Działa ona na ograniczonej liczbie wspomnień i aktywuje jedynie niektóre odczucia lub tendencje, ${ }^{13}$

Afekty są więc i bardziej złożone, i trudniejsze do interpretacji od emocji, zawierając w sobie zawsze element potencjalności:

Tym, co nazywam afektem w tym tekście, jest dokładnie ta podwójność, równoczesna partycypacja tego, co możliwe, w tym, co aktualne i tego, co aktualne, w tym, co możliwe, gdyż jedno powstaje ze zwrotu ku drugiemu. Afekt jest podwójny, gdy widzimy go ze strony aktualności, jako formowany za pomocą percepcji i poznania. ${ }^{14}$

Już w Parables for the Virtual Massumi zwracał uwagę, że afekty są tak interesującą kategorią badawczą, ponieważ pozwalają na badanie różnych fenomenów na przynajmniej kilku płaszczyznach: dyskursywnej, cielesnej, ale i politycznej. Z tego powodu, choć teoria afektów jest tworzona głównie na gruncie filozofii (podwaliny pod nią stworzył Baruch Spinoza, a - w bardziej współczesnych nam czasach - Henri Bergson, czy wreszcie Félix Guattari i Gilles Deleuze), to już jej użycie, zwłaszcza polityczne, przekracza granice filozofii i jest raczej domeną studiów kulturowych, a dalej - praktyki kulturowej ${ }^{15}$. Również w tym kierunku idą rozważania Massumiego, a zwłaszcza koncepcja ontosiły (ontopower).

By wyjaśnić, czym ma być ontosiła i wytłumaczyć, dlaczego tak wiele miejsca przeznaczam na omówienie teorii Massumiego, muszę poświęcić

12

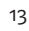

14

Tamże, s. 217.

Tamże, s. 5. Jeśli nie zaznaczono inaczej, tłumaczenia z języka angielskiego są tłumaczeniami autora.

B. Massumi Parables for the Virtual, s. 35 .

Tamże, s. 244-256. 
jeszcze chwilę na wytłumaczenie kolejnego istotnego dla badacza pojęcia. Tym pojęciem jest preemption, czyli rodzaj strategii ofensywnej, która polega na udaremnieniu, zapobieżeniu przyszłemu zdarzeniu. Tak rozumiane udaremnienie nie jest - co badacz podkreśla - prewencją, gdyż nie dotyczy sytuacji, w których zapobiegamy możliwemu do zidentyfikowania, realnemu zagrożeniu. Ta strategia opiera się na czymś zgoła innym - jest to działanie w teraźniejszości przeciwko przyszłej, nieistniejącej jeszcze groźbie ${ }^{16}$.

Przedstawiona przez Massumiego interpretacja udaremnienia (preemption) jest bardzo istotna, gdyż pokazuje ona, w jaki sposób zarządzanie afektami przekłada się na doraźne decyzje polityczne. Skoro - jak wskazuje badacz - cała doktryna opiera się na odwróconym schemacie czasowym i zmienionym wektorze zależności (przyszła groźba nie musi być realna, ale jedynie możliwa, co w praktyce oznacza, że niemożliwe jest nawet precyzyjne ustalenie, z czyjej strony zagraża niebezpieczeństwo), to uzasadnienie dla podjęcia jakiejkolwiek akcji motywowanej tą strategią jest zawsze możliwe. Tym uzasadnieniem możne być strach, który skutecznie zmienia potencjalną, przyszłą groźbę w realne, teraźniejsze zagrożenie ${ }^{17}$.

Oczywiście, by taka zmiana się dokonała, i by była ona trwała, nie wystarczy samo wyobrażenie o przyszłej groźbie. Musi być ono odpowiednio osadzone w teraźniejszości i wizjach przyszłości, a - jak zauważa Massumi najłatwiej zrobić to za pomocą dobrze zorganizowanej wojny informacyjnej. Jedną z ciekawszych strategii, jakie Massumi pod tym względem analizuje, jest strategia funkcjonująca pod nazwą 'pokaż próbkę przyszłości' (sample the future). Zgodnie z nią, przyszłość jest widziana jako deszcz iskier, z których tylko jedna ma szansę - jeśli spadnie na odpowiedni grunt - zapłonąc ${ }^{18}$. Jednak dla potrzeb wojny informacyjnej, każda z tych iskier jest interesująca, każda ma szansę stać się przyszłością, a więc możemy wybrać dowolną (czyli niekoniecznie najbardziej prawdopodobną) z nich jako przykład mającej nastąpić, zagrażającej przyszłości. A to oznacza, że - jak twierdzi Massumi - po raz pierwszy żyjemy w czasach, w których to, co się nie wydarzyło, a jedynie mogło wydarzyć, może stanowić fakt ${ }^{19}$.

16 B. Massumi Ontopower. War, Powers, and the State of Perception, Duke University Press, Durham-London 2015, s. 7.

Por. s. 240.

19 Jako przykład takiej sytuacji Massumi podaje tytuł artykułu prasowego, "The Next Pandemic does not Exist Yet", tegoż Ontopower..., s. 189. 
Zjawisko, o którym pisze Massumi, stanowi część szerszego problemu, który można określić jako kryzys kategorii faktu. Pojęcie to, odnoszące się pierwotnie do rzeczy lub wydarzeń, do których doszło w rzeczywistości, zaczyna ulegać postępującemu rozmyciu. Faktami stają się rzeczy lub wydarzenia, które nigdy się nie zdarzyły, a jedynie mogły wydarzyć, jako fakty zaczynają również funkcjonować plotki lub domysły, co sprawia, że cała ta kategoria zostaje osłabiona. Rzeczywistość przestaje się jawić jako konieczna, a zaczyna funkcjonować jako możliwa, jako jedynie jedna z wielu opcji. To zaś sprawia, że status ontologiczny zarówno faktów, jak i realności, nie jest już sprawą jasną i niedyskutowalną.

Kryzys kategorii faktu sprawia, że możliwe staje się wytworzenie i działanie wzmiankowanej już ontosiły. Ta koncepcja filozoficzna i zarazem strategia polityczna wynika wprost z dostrzeżenia niestabilnego, chwiejnego statusu ontologicznego rzeczywistości, która zaczyna być postrzegana jako przypadkowa, wcale niekonieczna konsekwencja przeszłości. Pod tym względem strategia udaremniania jest częścią ontosiły, gdyż odnosi się do możliwej, a wcale niepewnej, ani nawet prawdopodobnej przyszłości, a zarazem - co jest jedną z najważniejszych cech ontosiły - ma zdolność wywierania wpływu na teraźniejszość. Działanie tej specyficznej władzy, polegającej m.in. na manipulacji opisem rzeczywistości, pokazuje np. mowa G.W. Busha, wygłoszona po przejściu huraganu Katrina, którą analizuje Massumi. Polityk podkreślał w niej, że wszystkie nadzwyczajne środki zostały podjęte nie po to, by - jak moglibyśmy się spodziewać - przywrócić ży ci e do nor malno ści, lecz po to, by przywró cić ży ci e. Ontosiła to więc zdolność do stawania się tym, czego siły są maksymalnie abstrakcyjne, czego siły sytuują się w konceptualnej perswazji. To siła powstawania, siła powtarzalnego tworzenia wariantów przyszłości, należących do tego samego kształtu lub tendencji, które zarazem stanowią uzasadnienie dla zmiany aktualnych warunków życia ${ }^{20}$.

\section{Przyszłość afektywnych faktów}

Ten dłuższy wstęp, poświęcony rozwijanym przez Massumiego koncepcjom, prowadził do zarysowania zasadniczej dla tego artykułu kwestii, czyli problemu polityczności afektów i ich relacji z kształtowanymi wizjami przeszłości i przyszłości. Do tego zagadnienia nawiązywał już zresztą tytuł artykułu, a dokładniej zawarta w nim fraza 'przeszłe przyszłości'. 
Termin ten jasno odwołuje się do ukutego przez Briana Massumiego określenia 'futures past'21. Tłumaczenie owego terminu jako "przeszłe przyszłości' nie należy może do najzgrabniejszych, ale najprościej oddaje znaczenie, jakie owemu sformułowaniu przypisuje badacz. Przeszła przyszłość to taka wizja przyszłości, która wprawdzie - jak pokazuje rzeczywistość nigdy się nie spełniła, ale która stanowi istotny komponent naszej teraźniejszości, wciąż pełniąc istotne funkcje w afektywnej ekonomii. Pod tym względem fenomen przeszłych przyszłości może być analizowany na dwa odmienne, lecz związane ze sobą sposoby: z jednej strony stanowi on część naszej pamięci o przeszłości, z drugiej jednak - wizje przeszłej przyszłości kształtują naszą teraźniejszość i jako takie są związane z aktualną, a nie minioną polityką afektywną. To zaś oznacza, że zjawisko to stanowi pomijany lub słabo dostrzegany sektor zarówno badań nad pamięcią, jak i nad afektami. By wytłumaczyć, dlaczego tak jest, warto odwołać się jednak nie tylko do teorii, lecz do praktyki, a jeszcze lepiej - do praktyki politycznych rozgrywek.

Tłumacząc to zjawisko, Massumi przypomina okoliczności, w jakich G.W. Bush starał się o reelekcję w 2004 roku. A były to okoliczności zdecydowanie dla polityka niekorzystne - wojna w Iraku, początkowo popierana przynajmniej przez część amerykańskiego społeczeństwa i czynnie wspierana przez wiele krajów europejskich okazała się totalną polityczną porażką, a prezydenta oskarżano coraz wyraźniej o rozpętanie jej bez żadnego istotnego powodu. Odpowiadając na owe zarzuty, G.W. Bush usytuował usprawiedliwienie dla podejmowanych przez siebie działań nie w teraźniejszości, nie w przeszłości nawet, lecz w przeszłej wizji przyszłości, która niegdyś - jego zdaniem i zdaniem jego popleczników - była realna. Fakt, że owa wizja nie okazała się prawdziwa, że nie zrealizowała się w teraźniejszości i nic nie pozwala przypuszczać, by miała stać się realna w przyszłości, nie odbierał sensu domniemaniu jej realności w chwili podejmowania decyzji o wojnie w Afganistanie:

Inwazja była usprawiedliwiona, bo w przeszłości istniała przyszła groźba. Nie da się usunąć takiego „faktu”."22

Por. B. Massumi The Future Birth of the Affective Fact. The Political Ontology of Threat, w: The Affect Theory Reader, ed. by M. Gregg, G.J. Seigworth, Duke University Press, Durham-London 2010, S. 52 oraz B. Massumi Ontopower... 
Strategia G.W. Busha, jak pokazuje historia i jak przypomina Massumi, zadziałała. Polityk wygrał ponownie wybory, piastując urząd prezydenta przez następne cztery lata. To zaś oznacza, że prezentowana przez niego wizja przeszłej przyszłości okazała się na tyle realna, że wciąż wywoływała silną afektywną reakcję w sporej części społeczeństwa. Dlaczego tak się stało? Ponieważ, jak argumentuje badacz, oparta była na poczuciu zagrożenia, na strachu przed niepewną, a mającą nieuchronnie nadejść przyszłością. Massumi w cytowanym eseju The Future Birth of the Affective Fact opisuje fenomen oddziaływania afektywnych faktów, które - jak wyjaśnia - istnieją i działają na społeczeństwo bez względu na to, czy są zakorzenione w rzeczywistości, czy też nie.

Jednym z takich afektywnych faktów jest poczucie zagrożenia. Jeśli raz je odczujemy, jeśli raz wyzwoli się w nas afektywna reakcja, nic już nie jest w stanie owego afektu zmienić, odwołać ani unieważnić. Jeśli odczuję zagrożenie w przeszłości, to nawet jeśli owo zagrożenie nie przekształci się w realne działanie przeciwko mnie, zawsze pozostanie zagrożeniem. Żadna przyszłość go nie zmienii ${ }^{23}$.

Analiza tak rozumianych afektywnych faktów (affective facts) prowadzi Massumiego do - rozwijanego zwłaszcza w książce Ontopower, War, Powers, and the State of Perception - spostrzeżenia, że współczesna polityka opiera się na afektywnych faktach i afektywnej ekonomii. Tworzenie i kontrolowanie afektów jest więc jednym z istotniejszych zadań polityki XXI wieku, zwłaszcza w USA, która zbudowała sporą część swojej strategii obronnej na koncepcji udaremniania (preemption) ${ }^{24}$ przyszłych zagrożeń. Symbolicznym momentem narodzin owej polityki, a zarazem nowej ery zarządzania afektami i kierowania społeczeństwem ma być 11 września 2001. Spowodowany nim wstrząs doprowadził amerykańskie społeczeństwo do punktu, w którym przypisywane G.W. Bushowi twierdzenie, że jeśli czekamy na to, by groźby lub zagrożenia stały się realne, to oznacza to, że czekamy zbyt długo ${ }^{25}$, spotkało się ze zrozumieniem. A zrozumienie stało się pierwszym krokiem do uznania kuriozalnej w gruncie rzeczy logiki, zgodnie z którą podejmuje się i usprawiedliwia działania przeciwko nierealnym zagrożeniom.

Tamże, s. 54-55.

Tamże, s. 55 oraz B. Massumi Ontopower..., s. 5. 
Na pierwszy rzut oka koncepcja Massumiego przypomina znany już filozoficzny problem istnienia światów możliwych, a przeszłe przyszłości można odczytywać jako niezrealizowane alternatywne rzeczywistości. Oczywiście, Massumi czerpie z tej starej, filozoficznej intuicji, niemniej daje się zauważyć spore różnice w tych koncepcjach. Pierwsza z nich dotyczy funkcji: światy możliwe wiązały się początkowo ściśle z problematyką logiczną, a dokładniej z semantyczną interpretacją logik modalnych, uznających operatory możliwościowe i koniecznościowe (co z kolei było skorelowane z prostym skądinąd spostrzeżeniem, że istnieją zdania logiczne, które nie są prawdziwe ani fałszywe, jak „Jutro będzie padał deszcz"). Dla decydowania o wartości logicznych takich zdań potrzebne było stworzenie - początkowo wyłącznie teoretycznej - konceptualnej kategorii światów możliwych (zdanie „)utro będzie padał deszcz", jeśli będzie opatrzone operatorem możliwości, będzie prawdziwe, bo możemy pomyśleć świat, w którym będzie jutro padało, ale fałszywe, jeśli będzie opatrzone operatorem konieczności, gdyż jestem również w stanie pomyśleć świat, w którym jutro będzie cały dzień słonecznie). Kolejne różnice dotyczą już bardziej szczegółowych kwestii: pierwszym filozofem, który uznał realność istnienia światów możliwych i zdefiniował je przez odniesienie do codziennej intuicji, że rzeczy mogłyby być inne, niż są, był David Lewis ${ }^{26}$. Pozostaje on zresztą jedynym z ważnych myślicieli XX wieku, którzy opowiadają się za realnością i aktualnością światów możliwych, w przeciwieństwie do m.in. Saula Kripkego ${ }^{27}$ czy Roberta C. Stalnakera ${ }^{\mathbf{2 8}}$, którzy definiują światy możliwe w kategoriach abstrakcyjnych (są to wtedy po prostu sądy w sensie logicznym). Niemniej, nawet Lewis, uznawany za konkretystę, który twierdzi, że światy możliwe istnieją realnie i aktualnie, nie dopuszcza możliwości kontaktu między owymi światami (czyli istnieją wprawdzie inne światy możliwe, ale aktualny jest dla nas zawsze ten, w którym przebywamy i nie ma możliwości wyjścia z niego). To właśnie stanowi o największej różnicy między nawet najbardziej realnie interpretowaną teorią światów możliwych, a koncepcją przeszłych przyszłości - przeszłe przyszłością są częścią naszego aktualnego świata, nie zaś innym światem, realnym, lecz nie dla nas.

D. Lewis Countrfactuals, Harvard University Press, Cambridge, MA 1973.

S. Kripke Nazywanie a konieczność, przeł. B. Chwedeńczuk, Instytut Wydawniczy PAX, Warszawa 1988. 
Przedstawione wcześniej przeze mnie koncepcje funkcjonowania afektów i przeszłych przyszłości i porównanie ich do światów możliwych prowadziły do tego w gruncie rzeczy prostego, ale jednak poruszającego i niepokojącego stwierdzenia: gdy coś raz zostanie odczute jako realne, gdy stanie się podstawą afektywnej reakcji, staje się faktem. Afektywnym faktem, ale faktem, którego nie da się zmienić, przekreślić ani unieważnić. Tak rozumiany afektywny fakt jest z kolei podstawą funkcjonowania przeszłych przyszłości, stanowiących nie alternatywną rzeczywistość, lecz aktualną rzeczywistość.

Fenomen afektywnego oddziaływania przeszłych przyszłości, który na amerykańskim gruncie tak dobrze opisuje Brian Massumi, wręcz domaga się interpretacji także w odniesieniu do polskiej polityki i poetyki pamięci. Nawet krótka i pobieżna obserwacja współczesnych dyskusji politycznych, toczonych na polskim gruncie, pokazuje, jak istotną rolę odgrywa w niej z jednej strony przeszłość i pamięć o niej, z drugiej zaś - wciąż pielęgnowane, choć już niemożliwe do zrealizowania, wizje przeszłych przyszłości. Poszczególne partie polityczne rozliczają się przecież wzajemnie dość często nie z tego, co jedna lub druga zrobiły lub czego nie zrobiły, lecz z tak zwanych zaprzepaszczonych szans, które - jeśliby spojrzeć na nie przez pryzmat teorii Massumiego - nie są przecież niczym innym niż zepsutymi, niezrealizowanymi wizjami przeszłej przyszłości.

Ze współczesnej perspektywy nietrudno zauważyć, że takimi momentami, które szczególnie mocno wyzwalają dyskusje dotyczące zniweczonej, lecz niegdyś możliwej nie tylko do pomyślenia, lecz do osiągnięcia teraźniejszości, są zarówno transformacja polityczna roku 1989, jak i - wciąż zaskakująco obecna w polskiej kulturze - II wojna światowa. Te dwa przełomowe momenty z XX-wiecznej historii wciąż stanowią punkty afektywnych zapętleń, w których pamięć o wydarzeniach miesza się z zawiedzionymi nadziejami, a rozmaite przeszłe przyszłości nakładają się na siebie, tworząc kolejne afektywne fakty.

Warto moim zdaniem spojrzeć z tej perspektywy na polską literaturę i kulturę ostatnich dwudziestu pięciu lat, a szczególnie na jeden z jej istotnych nurtów, który opiera się na mniej lub bardziej afektywnych, mniej lub bardziej refleksyjnych, ale wciąż bardzo wyrazistych próbach powrotów do problemów związanych z pamiętaniem II wojny światowej. Analizując takie teksty kultury, których - jeśli by spojrzeć na polską kulturę ostatnich choćby dziesięciu lat - jest niemało (a należą do nich i masowo czytane książki Szczepana Twardocha, i kolejne filmy dotykające tej problematyki, włącznie 
z Ida, Miastem 44 i Wotyniem, by wymienić tylko najpopularniejsze) trudno oprzeć się wrażeniu, że wypełniają one w pewien paradoksalny sposób lukę wczesnych lat 90. i - jasno sygnalizowany przez krytyków i badaczy - czas oczekiwania na teksty kultury 'na miarę czasów', dotyczące transformacji $1989 \mathrm{roku}^{29}$.

\section{Alternatywne historie i afektywny optymizm}

W tej części artykułu chciałabym przyjrzeć się szerzej tylko jednej, za to dość specyficznej powieści, dotyczącej wspominanej problematyki. Jest nią Rzeczpospolita zwycięska Ziemowita Szczerka, przedstawiająca specyficzną, alternatywną wersję polskiej historii. Książka ta eksploruje dobrze znane pytanie 'co by było, gdyby Polska wygrała II wojnę światową?'. Opiera się więc ona w swych założeniach na podobnym schemacie, jak wydana zaledwie rok wcześniej książka Marcina Wolskiego Wallenrod ${ }^{30}$, jednak - w przeciwieństwie do tekstu Wolskiego, nie jest powieścią. W Wallenrodzie mamy przedstawioną wersję historii, w której Polska pod dowództwem Józefa Piłsudskiego (który, dzięki nowatorskiej terapii, nie umiera w 1935 roku) sprzymierza się z Niemcami i dokonuje podboju Rosji. Jednakże sojusz z Niemcami jest tyleż skuteczny w rozwiązaniu problemu z Rosją, co nietrwały, przez co kluczowe dla prowadzonej narracji są losy fikcyjnego polskiego szpiega, Heleny Wichman.

Książka Szczerka opiera się na zupełnie innym założeniu. Nie ma w niej przynajmniej w zamierzeniu - ani elementów fantastycznych, ani fikcjonalnych postaci. Nie dzieje się nic, co byłoby niemożliwe, choć z całą pewnością dzieją się rzeczy mało prawdopodobne. Zamiast - jak w przypadku Wallenroda - tworzyć fikcjonalno-fantastyczną powieść, Szczerek stara się raczej skomponować pewną możliwą do pomyślenia i zrealizowania wizję II wojny światowej. Owa wizja utkana jest z mniej lub bardziej realistycznych nadziei dotyczących przyszłości, i to zarówno tych nadziei, które były charakterystyczne dla lat 30., jak i tych, które wciąż powracają w odniesieniu do II wojny światowej współcześnie. Ta specyficzna budowa odróżnia ją także od innych, ważnych i cennych książek dotyczących alternatywnych wersji

29 Por. P. Czapliński Ślady przełomu, Wydawnictwo Literackie, Kraków 1997 oraz Codzienne, przedmiotowe, cielesne. Języki nowej wrażliwości w literaturze polskiej XX wieku, red. H. Gosk, Świat Literacki, Warszawa 2002. 
polskiej historii, m.in. od pisarstwa Jacka Dukaja. Dlatego też analizuję ją jako przypadek od powieści fikcjonalnych osobny, opierający się nie tyle na fantastycznej narracji, co na pewnym eksperymencie myślowym. To zaś zbliża ją raczej do rozważań historyków ${ }^{31}$, niemniej od tych odróżnia ją teraźniejszy, współczesny punkt wyjścia, który czyni przeszłość wstępem do rozmowy o przyszłości.

Tekst Szczerka opiera się na wizji przeszłej przyszłości, motywowanej nie jak było w przypadku opisywanych przez Massumiego zjawisk - zagrożeniem, strachem lub poczuciem niepewności, lecz nadzieją i optymizmem, które często uznaje się za znak rozpoznawczy krótkiego okresu międzywojennego. Książka z 2013 roku stanowi próbę odpowiedzi na powtarzane od lat pytanie, jakim krajem byłaby Polska, gdyby krótkiego, dwudziestoletniego okresu zjednoczenia po I wojnie światowej, nie przerwała II wojna światowa lub gdyby okazała się ona dla Polski zwycięska ${ }^{32}$. Szczerek opiera swoją alternatywną wizję historii na faktach, starając się znaleźć lub wytworzyć taką wersję rzeczywistości, w której kampania wrześniowa nie byłaby przegrana tak szybko, co z kolei pozwalałoby mieć przynajmniej nadzieję na francuską, a w dalszej perspektywie również angielską i amerykańską pomoc. Techniczne szczegóły takiej wersji historii, choć interesujące, są z punktu widzenia tego artykułu mało istotne, przytoczę więc tylko cztery najważniejsze zmiany w stosunku do rzeczywistej historii, polegające na: oparciu polskiej obrony na linii Wisły, szybkiej i mocnej pomocy Francji, przełamaniu linii Zygfryda przez wojska alianckie w pierwszych tygodniach wojny i braku interwencji Rosji. Ważniejsze od przebiegu tak projektowanej wojny, jest to, co nastąpiło przed nią, i to, co nastąpiło po niej.

Punktem wyjścia książki Szczerka jest opis - w całości faktualny, opierający się na analizie źródeł historycznych - dni poprzedzających wybuch wojny i pierwszych chwil kampanii wrześniowej. A tym, co zdaniem autora najbardziej rzuca się w oczy, jest niesamowity wręcz optymizm, by nie powiedzieć - absolutne wyparcie faktów:

31 Bez wątpienia Szczerek opiera się w swojej książce na części argumentów analizowanych m.in. przez Andrzeja Nowaka, niemniej - pozostaje wobec nich polemiczny.

W pewnym sensie książkę tę można traktować jako próbę sprawdzenia, co o współczesnej polityce mówi nam potrzeba tworzenia takiej utopijnej wizji Polski. Pod tym względem tekst ten można odczytywać zgodnie z teorią Frederica Jamesona, ukazującego polityczny wymiar utopii literackiej, por. F. Jameson Archeologie przyszłości. Pragnienie zwane utopiq̨ i inne fantazje naukowe, przeł. M. Płaza, M. Frankiewicz, A. Miszk, Wydawnictwo UJ, Kraków 2011. 
Ktoś, kto by w pierwszych dniach września 1939 roku czerpał wiedzę o wydarzeniach na froncie wyłącznie z polskiej prasy, odniósłby wrażenie, że Rzesza najdalej za parę dni padnie i już się nie podniesie..$^{33}$

Opis tego specyficznego momentu historycznego zajmuje w książce Szczerka cały prolog, zatytułowany „Prawdziwe kłamstwa wrześniowej prasy”. Taki, a nie inny początek jest znaczący, określa bowiem dobrze afektywne fakty, jakie stały się podstawą wytworzenia wizji Rzeczpospolitej zwycięskiej, wizji, która przecież nie jest tylko literacką fantazją Szczerka, lecz podzielanym w aktualnych dyskusjach politycznych stanem rzeczy, kreującym do pewnego stopnia współczesną polską politykę afektów.

Na przedstawioną przez Szczerka sytuację można spojrzeć również za pomocą narzędzi interpretacyjnych nawiązujących do koncepcji innej badaczki, zajmującej się afektami. Mam tu na myśli Lauren Berlant i jej kategorię okrutnego optymizmu (cruel optimism). W książce na ten temat, Berlant zauważa, że optymizm to przekonanie, że to, czego pragniemy, jest dla nas dostępne i możliwe do osiągnięcia. A każdy przedmiot pożądania jest przez nas w gruncie rzeczy postrzegany jako zespół obietnic, które mogą stać się dla nas możliwe do realizacji. Owe obietnice mogą być ucieleśnione w osobie, rzeczy, instytucji, tekście, normie, zapachu, dobrym pomyśle - we wszystkim ${ }^{34}$. Jednakże, jak zauważa badaczka, nie zawsze wybieramy przedmiot naszego pożądania tak, by rzeczywiście mógł się on przyczynić do realizacji istotnych dla nas celów, by zawierał w sobie istotne dla nas obietnice. Okrutny optymizm to zatem przywiązanie do rzeczy, idei lub osób, które przeszkadzają nam w rozwoju lub rozkwicie. Dla Berlant przykładem tak rozumianego okrutnego optymizmu może być choćby fantazja o dobrym życiu. Nietrudno zauważyć, że opisywany przez Szczerka optymizm z początków kampanii wrześniowej to również okrutny optymizm, który przyczyniał się nie tylko do podejmowania złych decyzji, ale i do budowania fantazmatu dotyczącego możliwych wersji przyszłości. Wersji przeszłości, które choć nigdy nie zostały zrealizowane, w dalszym ciągu funkcjonują - jak powiedziałby z kolei Brian Massumi - jako afektywne fakty.

To zaś oznacza, że książka dotycząca alternatywnej wersji historii tylko po części wytwarza określoną wizję przeszłości, w większym stopniu - mierzy się z jej kształtem:

Z. Szczerek Rzeczpospolita zwycięska. Alternatywna historia polski, Znak, Kraków 2013, s. 7. 
Będzie to wizja Rzeczypospolitej, której - choć na pewien czas - udało się być taką, jaką sama by się chciała widzieć, gdyby spełniły się jej sny o idealnej sobie samej: o potędze, o posiadaniu kolonii, o modernizacji, o europeizacji, o stworzeniu Międzymorza, o ambicjach odgrywania wielkiej regionalnej, co tam regionalnej - światowej roli. [...]

Od zawsze wyobrażamy sobie tę mocarstwową Polskę, ale jakby po trochu, fragmentarycznie. Nigdy całościowo. Nikt nigdy nie nakreślił jednej, spójnej wizji takiej mocarstwowej Polski. ${ }^{35}$

Powyższy cytat jasno pokazuje, że książka Szczerka nie jest w istocie książką o II wojnie światowej. W rzeczywistości jest ona książką na temat określonej wizji modernizacji Polski, wizji, do której chętnie odwołują się prawicowe media i politycy. W narracji, którą podejmuje Szczerek, nie było wielkiej wyrwy II wojny światowej, losy Polski były więc kontynuacją drogi, którą kraj zaczął kroczyć w okresie współcześnie idealizowanego dwudziestolecia międzywojennego. W rozdziale Kraj, który przetrwat Szczerek opisuje przypuszczalną kontynuację polskiej polityki wewnętrznej, zmierzającej - za czasów rządów sanacji - do polityki autorytarnej, niewiele - jeśli w ogóle różniącej się na plus od dzisiejszych rządów w Białorusi. Co ciekawe, autor odwołuje się przy tym do rzeczywistych rozwiązań z okresu przed II wojną światową, a zwłaszcza - narastającego kultu jednostki. Warto zacytować jeden z bardziej interesujących fragmentów:

W 1938 roku uchwalono Ustawę o ochronie Imienia Józefa Piłsudskiego (tak, ,imię" pisano od dużej litery), którego w rzeczonym akcie prawnym oficjalnie i z pełną powagą nazywano (znów wielkie litery) „Wskrzesicielem Niepodległości Ojczyzny” i „Wychowawcą Narodu”.36

W alternatywnej wersji historii nie mamy jednak do czynienia wyłącznie z kultem Piłsudskiego. Równie ważną rolę w polskiej polityce zaczyna odgrywać Edward Rydz-Śmigły, dowódca zwycięskiej armii i nowy polski mąż opatrznościowy. Staje się dominującą postacią polskiej sceny politycznej, a jego poczynania i forma rządów przypomina rolę, jaką obecnie pełni Władimir Putin w Rosji. Wpływ Rydza-Śmigłego na losy Polski jest tak silny, że znajduje odzwierciedlenie również poza warstwą fikcjonalną książki, niejako

Z. Szczerek Rzeczpospolita zwycięska..., s. 10. 
wychodząc poza ramy prowadzonej przez Szczerka, świadomej własnej fikcjonalności narracji. Znajdujemy go bowiem także w redakcyjnym opisie książki, gdzie na okładce, obok daty i miejsca wydania, znajduje się adnotacja: „wydano nakładem Instytutu Myśli i Słowa Czynu Śp. Naczelnego Wodza Edwarda Śmigłego". Umieszczenie owej adnotacji jest gestem znaczącym, gdyż łamie ona budowaną od pierwszych stron książki umowę z czytelnikiem. $\mathrm{W}$ jej ramach jesteśmy informowani o czysto spekulatywnym charakterze tekstu, w którym wygrana wojna jest tylko alternatywną historią i nigdy nie miesza się z historią rzeczywistą, która przypadła nam w udziale. Konwencji tej nie łamie również dołączony do książki fikcjonalny reportaż, opowiadający o kształcie Polski w latach nam współczesnych, gdyż jest on od początku zapowiadany jako inna forma historii alternatywnej, w której autor dzieli się z nami jeszcze bardziej subiektywną wizją teraźniejszości, mogącej być choć wcale niekoniecznie - następstwem alternatywnego rozwoju historii. Wspomniana adnotacja jest więc jedynym tego typu złamaniem konwencji tekstu.

W prowadzonej przez Szczerka narracji ogromną rolę odgrywa próba odpowiedzi na pytanie, co - poza wygraną, a w każdym razie nieprzegraną wojną - musiałoby się wydarzyć, by dokonała się modernizacja Polski. Odpowiedź jest dość prosta i nie spodobałaby się ani ówczesnym, ani współczesnym konserwatystom utrzymującym mit silnej Polski międzywojennej: musiałaby otrzymać pomoc z zewnątrz, zarówno polityczną, sankcjonującą jej mocną pozycję w regionie, jak i finansową (jak wskazuje autor - musiałby to być Leand-Lease Act połączony z planem Marshalla). Dlaczego? Na to pytanie Szczerek odpowiada dość brutalnie:

Bo Polska sama z siebie nie miałaby jak osiągnąć tej swojej wyśnionej potęgi. Rzeczypospolita była biedna jak mysz kościelna: wystarczy przypomnieć, że jednym z powodów tego, że tak mocno sprzeciwialiśmy się powstawaniu nieszczęsnej eksterytorialnej autostrady łączącej Rzeszę z Prusami i Gdańskiem był fakt, że cła pobierane od Niemców za tranzyt przez polskie terytorium stanowiły bardzo istotną część budżetu. Bez nich mógłby się zawalić. ${ }^{37}$

Ponownie, lista rzeczy, które musiałyby się wydarzyć, by Polska stała się choćby 'liderem regionu', jest długa i z perspektywy tego artykułu nie aż tak 
ciekawa. Bardziej interesujące jest, to, co by się stało, gdyby sen o potędze i modernizacji się ziścił. Diagnoza Szczerka opiera się na prostym założeniu: Polska nie zmieniłaby się z dnia na dzień w nowoczesne państwo, bo w gruncie rzeczy wcale nie chciała być nowoczesnym państwem, lecz - cokolwiek to słowo znaczy - mocarstwem. Była więc w stanie zaakceptować i wdrożyć tylko te zmiany, które mogły w prosty sposób przyczynić się do polepszenia jej obrazu w obliczu opinii międzynarodowej.

Wzmocniona międzynarodowymi pożyczkami, namaszczona na lidera regionu i odgrywająca istotną rolę w powstającym w historii alternatywnej Międzymorzu Polska śniłaby więc swój sen o imperializmie, o koloniach (włącznie ze słynnym w dwudziestoleciu pomyśle założenia polskiej kolonii na Madagaskarze), o utworzeniu Polsko-Słowacji, o okupacji Prus Wschodnich i Śląska (które raczej nie stałyby się po prostu częścią Polski po wygranej II wojnie światowej), a równocześnie w dalszym ciągu nie radziłaby sobie z problemami wewnętrznymi. Z mniejszościami, których po tak zakończonej wojnie przybyłoby, z antysemityzmem jako narastającym problemem społecznym czy wreszcie z przypuszczalnie nabierającym siły separatyzmem ukraińskim (a skalę tego zjawiska można by akurat dość precyzyjnie przewidzieć, biorąc pod uwagę wydarzenia z Wołynia z 1943 roku) i prawdopodobnie pojawiającymi się kolejnymi separatyzmami.

Wspomniane problemy - jeśliby nie było silnej woli ich rozwiązania skutecznie blokowałyby jakiekolwiek możliwości rzeczywistego modernizowania kraju. A wcześniej czy później doprowadziły również do rozpadu tak pożądanego sojuszu i radykalnej marginalizacji Polski na arenie międzynarodowej. Podsumowaniem wizji Polski, jaką snuje Szczerek, jest dołączony do książki Reportaż z II Rzeczypospolitej, z alternatywnego roku 2013. Wszystkie sugerowane w historii alternatywnej problemy narastają, a poszczególne separatyzmy przekształcają się w regionalny terroryzm. Zamiast konstruktywnego radzenia sobie z takimi problemami, Polską odpowiedzią na wewnętrzne kryzysy są próby tworzenia narodowej mitologii, której wyraźne ślady można znaleźć i we współczesnej polityce. Jednym z nich jest Świątynia Opatrzności Bożej:

Po kilkudziesięciu metrach betonowe monstrum jeszcze bardziej spotworniało i rozszerzyło się w plac, a właściwie forum okolone kolumnami jak w modernistycznej wizji starożytnego Rzymu. Sterczało nad tym wszystkim inne betonowe straszydło przypominające przedwojenny wieżowiec skrzyżowany z ufortyfikowanymi koszarami. Nad wejściem 
do tego bryliszcza widniała rozeta. No tak. Więc to jest kościół Opatrzności Bożej... ${ }^{38}$

Diagnoza Szczerka jest tym ciekawsza, że tekst - wydany w 2013 roku, a napisany zapewne wcześniej - zdaje się doskonale diagnozować kierunek, $\mathrm{w}$ jakim obecnie zmierza zarządzana przez skrajnie konserwatywną partię Polska. To dążenie nie do modernizacji, nie do unowocześnienia rozumianego jako nie tylko progres gospodarczy i ekonomiczny, ale też przyjęcie określonych wartości ${ }^{39}$, lecz do spełniania określonych fantazji na temat miejsca Polski w Europie, a przy bardziej wybujałych ambicjach - w świecie. To dążenie do imperializmu w starym stylu, do zajęcia miejsca, jakie kiedyś zajmowało np. imperium brytyjskie. Lecz to marzenie - zarówno w wizji Szczerka, jak i we współczesnej Polskiej polityce - ma spełnić się nie na drodze rozwoju i modernizacji kraju, lecz jakiegoś dziwnego nadania Polsce określonego statusu mocarstwa przez inne państwa ${ }^{40}$.

Książka Szczerka dotyczy więc w głównej mierze rozdźwięku między wyobrażeniem o byciu mocarstwem, a byciem nowoczesnym państwem o silnej pozycji międzynarodowej. Ten rozdźwięk oddaje dobrze fragment jednego z kończących książkę dialogów:

Chcieliśmy polonizować wschodnie Niemcy, a nie jesteśmy w stanie zagospodarować Prus. Chcieliśmy kolonii, a nie mieliśmy floty ani żadnych tradycji morskich [...][...]. A przecież mocarstwo nie skamle, że mu się należy, mocarstwo sobie bierze, jeśli potrzebuje. Bierze i przede wszystkim potrafi utrzymać. ${ }^{41}$

Przedstawiłam tu dość obszernie prowadzoną przez Szczerka historię alternatywną nie dlatego, że uważam ją za szczególnie prawdopodobną lub

38 Tamże, s. 240.

39 Na konieczność takiego właśnie definiowania modernizacji zwracali m.in. uwagę Bjorn Wittock oraz Shmuel Noel Eisenstadt. Por. B. Wittock Modernity: One, None or Many? European Origin and Modernity as a Global Condition, w: Multiple Modernities, ed. by S.N. Eisenstadt, New Brunswick-London 2005, s. 31 oraz S.N. Eisenstadt Multiple Modernities, w: Multiple Modernities, s. 5. autora, pisze także Błażej Szymankiewicz. Por. tegoż Wschód i Środek jako stany umysłu, czyli mentalna kolonizacja w tekstach Ziemowita Szczerka, "Czas Kultury" 2016 nr 4. 
wyjątkowo przenikliwą. Jej słabości wypunktował m.in. Przemysław Czapliński, zauważając, że przedstawiona przez autora wersja modernizacji przypomina w gruncie rzeczy ten jej wariant, który został przeprowadzony w okresie PRL- $u^{42}$. Główny zarzut Czaplińskiego wobec proponowanej przez autora Rzeczpospolitej zwycięskiej wizji unowocześnienia Polski dotyczy roli ziemiaństwa. O ile Szczerek widział w nim szansę na wytworzenie sprawnie działającej nowej inteligencji, która może mieć pozytywny wpływ na potencjał modernizacyjny całego społeczeństwa, o tyle Czapliński widzi w nim raczej zagrożenie:

Autor nie zauważa, że w ten sposób hierarchia stanowa została zreprodukowana i ukryta w sferze państwowej - „panowie” nadal rządzą Polską, choć już nie z racji pochodzenia, lecz z racji kapitału kulturowego wyniesionego z domu i ułatwiającego im kończenie dobrych szkół wyższych. ${ }^{43}$

Choć Czapliński, analizując Rzeczpospolita zwycięska, interesuje się głównie przedstawioną w niej koncepcją Międzymorza, a więc szerokiego sojuszu pionowego, który miał szansę łączyć Polskę z innymi krajami regionu, a szczególnie Czechami i Węgrami, dostrzega również, że kreowana przez pisarza wizja modernizacji jest wizją niepełną, opartą na sprzecznościach i w gruncie rzeczy - zbyt wierną temu wszystkiemu, co wydarzyło się po przegranej wojnie. Z tego powodu Czapliński twierdzi, że II wojna światowa w historii alternatywnej jest nie tyle wojną wygraną, lecz jedynie wojną nieprzegraną lub unikniętą ${ }^{44}$, a jakakolwiek modernizacja, nawet niepełna, jaką przedstawia Szczerek, nie mogłaby się udać bez co najmniej trzech reform: obszarowej, klasowo-edukacyjnej i prawno-równościowej ${ }^{45}$.

\section{Optymistyczne barwy przeszłości}

Poświęciłam sporo uwagi sposobowi, w jaki Czapliński interpretuje książkę Szczerka nie bez przyczyny. Badacz w swojej najnowszej książce tworzy

P. Czapliński Poruszona mapa. Wyobraźnia geograficzno-kulturowa polskiej literatury przełomu XXiXXI wieku, Wydawnictwo Literackie, Kraków 2016, s. 308.

44 Tamże, s. 308. 
bowiem bardzo interesującą koncepcję, w której śledzi, w jaki sposób kształtuje się - i zmienia - wyobrażona mapa Europy i jakie miejsce zajmuje w niej Polska. Główne kierunki analizy wyznaczają dwie osie geograficzne i interpretacyjne: wschód-zachód i północ-południe. Ziemowit Szczerek jest pod tym względem raczej pisarzem, którego zainteresowania sytuują się na tej pierwszej osi, a - w miarę upływu czasu - coraz mocniej ciążą ku wschodowi. Silniejszym punktem odniesienia dla Szczerka, ale i - co Czapliński już na pierwszych stronach swojej książki zauważa - dla całej polskiej kultury, jest Rosja. Oczywiście jest to Rosja wyobrażona, traktowana jako „byt dyskursywny, tworzony przez reportaże, powieści, przekazy historyczne i doniesienia prasowe" ${ }^{46}$.

Wbrew pozorom także w przypadku Rzeczpospolitej zwycięskiej Rosja stanowi istotny punkt porównania. Nietrudno zauważyć, że wizja funkcjonowania przywódców państwowych w nietkniętej wojną Polsce opiera się na dwóch przykładach: sanacyjnej Polski z okresu lat 30. i współczesnej Rosji i Białorusi. Pod tym względem Rzeczpospolita zwycięska jest zapowiedzią późniejszych książek Szczerka, zwłaszcza zaś - o wiele lepiej odebranego przez publiczność Przyjdzie Mordor i nas zje i już całkowicie fikcjonalnej powieści Siódemka.

W obu przypadkach konfrontacja $\mathrm{z}$ wyobrażonym wschodem ma określone cele i zadania. Zwłaszcza w Siódemce wschód jest synonimem rozkładu, swoistą czarną dziurą, która pochłania każdego, kto znajdzie się odpowiednio blisko:

- Wschód - perorowałeś - rozpierdoli też w końcu Rosjan, zresztą już ich kilka razy rozpierdolił, tylko się zbierali, bo to wytrwały naród jak karakany [...] warują nad tym wschodem, nad tą pustką, jak Tolkienowski smok, który pilnuje swoich skarbów $[\ldots]^{47}$.

Z tego powodu Czapliński określa przedstawiane przez Szczerka próby scharakteryzowania Rosji jako szukanie polskiej formy ${ }^{48}$. Dzieje się tak przynajmniej częściowo dlatego, że dla określonej wizji polskości, do której w pewnym stopniu nawiązuje i Czapliński, i Szczerek, spore znaczenie ma miejsce, które Polska zajmuje w Europie. A jak zauważa fantastyczny bohater

\footnotetext{
46 Tamże, s. 15.

47 Tamże, s. 125.

P. Czapliński Poruszona mapa..., s. 174 .
} 
Siódemki, Bajaj (który pełni funkcję przewodnika duchowego dla wszystkich wierzących w potęgę Polski):

Polska jest centrum. Polska jest środkiem. Złotym środkiem. ${ }^{49}$

Jeśli spojrzymy z tej perspektywy na Rzeczpospolita zwycięska, łatwo dostrzec, że przedstawione w niej wersje rozwoju historii alternatywnej nawiązują do przekonania o centralnej pozycji Polski w Europie. Zgodnie z tym silnie zakorzenionym w polskiej kulturze fantazmatem, definiująca dla przyszłości Polski ma być jej pozycja geograficzna, determinująca wyróżnioną rolę kraju w Europie.

Wspominany fantazmat stanowi punkt wyjścia książki Szczerka i negatywny, ale wciąż istotny punkt odniesienia dla tworzonej przez Czaplińskiego relacyjnej mapy powiązań Polski z krajami ościennymi. Oczywiście, pisarz i badacz odnoszą się do tego fantazmatu w zasadniczo odmienny sposób: w Alternatywnej historii twórca nawiązuje do wyobrażenia o zajmowanej przez Polskę pozycji przed wojną i usiłuje sprawdzić, na ile uzasadnione jest przekonanie, że była to pozycja centralna lub wyróżniona, tymczasem Czapliński pokazuje, że na miejsce Polski w Europie da się patrzeć przez pryzmat zupełnie innych kategorii niż centrum czy peryferie. Jednak, bez względu na te zasadnicze różnice koncepcyjne, obie próby wyobrażenia miejsca Polski na mapie Europy muszą mierzyć się z wciąż jeszcze żywym, choć zupełnie nieuzasadnionym przekonaniem o domniemanej 'centralnej' pozycji Polski.

Przekonanie to można moim zdaniem traktować jako rodzaj afektywnego faktu, który stoi u podstaw stworzonej przez Szczerka wizji historii alternatywnej, zaprojektowanej tak, by wreszcie sprawdzić, czy rzeczywiście - w jakichkolwiek okolicznościach, choćby znacząco przekształconych - Polska mogła stać się hegemonem Europy. Mimo że - jak pokazuje rozwój przeprojektowanej historii - taka wizja pozycji Polski nie ma dobrego uzasadnienia ani w teraźniejszości, ani w przeszłości, pozostaje ona zaskakująco trwałym fantazmatem, mało podatnym na zmiany czy modyfikacje.

Wydaje się, że narzędziem przydatnym do analizy tego fenomenu jest właśnie stworzona przez Massumiego koncepcja przeszłych przyszłości i afektywnych faktów. Polska w XX wieku nigdy nie osiągnęła centralnej, stabilnej pozycji w Europie. Co ważne, nieczęsto można napotkać na twierdzenia, że tak się rzeczywiście stało - częściej padają sformułowania, że

Z. Szczerek Siódemka, Korporacja Ha!art, Kraków 2014, s. 197. 
byliśmy np. w okresie dwudziestolecia międzywojennego na dobrej drodze do osiagnnięcia takiej pozycji, że niechybnie by się to stało, gdyby nie II wojna światowa i - w konsekwencji - znalezienie się po złej stronie żelaznej kurtyny. A takie twierdzenia to nic innego, niż wizje przeszłych przyszłości, przyszłości, które mogły być kiedyś możliwe do osiągnięcia, ale nigdy się nie zrealizowały. Pozostają jednak w sferze zbiorowej świadomości jako afektywne fakty, które wciąż wpływają na pamięć o przeszłości i kreują - jak powiedziałaby Lauren Berlant - okrutny optymizm w odniesieniu do przyszłości.

Pamięć o przeszłości, do której odwołuje się Szczerek, jest więc pamięcią skrajnie afektywną. Wyobrażenia o przeszłej silnej pozycji, o możliwościach, które stały przed krajem otworem, o prawie powszechnym dobrobycie są utrzymane w zdecydowanie zbyt optymistycznych barwach, zbyt nasyconych poczuciem stabilizacji i oczekiwaniem na dobrą przyszłość. Owe pamięci funkcjonują zgodnie z opisanym przez Massumiego eksperymentem, w którym na początku XX wieku David Katz sprawdzał, jak respondenci pamiętają kolory, np. kolor oczu swojego przyjaciela ${ }^{50}$. Badania prowadzone przez Katza pokazały, że praktycznie wszyscy badani, dobierając pasujący kolor, wybierają zbyt jaskrawy, zbyt nasycony, zdecydowanie bardziej intensywny. A kiedy mogą sprawdzić, jak wypadł eksperyment, są skrajnie zaskoczeni jego wynikiem.

W przypadku pamięci o przeszłości i budowanych na niej wyobrażeniach dotyczących przyszłości, nie sposób skonfrontować wyobrażeń z rzeczywistą paletą kolorów. Niemniej, literatura i kultura może służyć - i wydaje mi się, że przynajmniej w przypadku opisywanych książek, koncepcji i teorii, rzeczywiście służy - za rodzaj probierza, który ułatwia nam konfrontację z tendencją do pamiętania i wyobrażania sobie przeszłości w wyjątkowo intensywnych kolorach. Dlatego też - jak pisałam wcześniej - wizja historii alternatywnej przedstawiona przez Szczerka nie musi być wcale wyjątkowo odkrywcza czy przenikliwa, by z punktu widzenia i badań nad afektami, i polską literaturą, była interesująca. Dzięki kategoriom i koncepcjom wywiedzionym ze studiów nad afektami można w niej zobaczyć swoisty afektywny eksperyment, który mówi nie o rzeczywistej przeszłości, lecz o afektywnych faktach, które wciąż kształtują naszą teraźniejszość. 


\section{Abstract}

\section{Justyna Tabaszewska}

THE INSTITUTE OF LITERARY RESEARCH OF THE POLISH ACADEMY OF SCIENCES (WARSAW)

Past Futures: Affective Facts and Alternative Histories

The goal of this article is to point to the future as a forgotten and understudied but still essential reference point for studies on memory and affects. Bringing B. Massumi's notion of'past futures' to bear on contemporary Polish literature, Tabaszewska demonstrates that concrete visions of the future are able to change our memories and impact our interpretation of the present. This means, therefore, that the future is - just as the past

- the domain of affective politics, the more liable to be manipulated as the future, unlike the past, is always only possible, never certain.

\section{Keywords}

future, affects, memory, ontopower, prose 